\title{
STRATEGI ORGANIZATIONAL DEVELOPMENT MELALUI APLIKASI PERSURATAN DAN KEARSIPAN ELEKTRONIK MY OFFICE DI UNIVERSITAS NEGERI YOGYAKARTA
}

\author{
Herman Setyawan \\ Mahasiswa MMPT SPS Universitas Gadjah Mada \\ herman.setyawan@ugm.ac.id
}

\begin{abstract}
Every organization is very necessary to develop along with the times. Organizations must be able to adapt to changes in various aspects of life, such as technological, economic, political, and cultural change. In facing change, a concept is needed to assist an organization in creating an effective response to this change. This paper is based on the development of My Office application of mailing and filing at Universitas Negeri Yogyakarta (UNY), especially in the Sub-Section of Administration and Filing as the key holder of the UNY Rectorate system, and then analyzed with the organizational development model developed by Kurt Lewin. With a qualitative-descriptive approach, this study attempts to answer the question: "How is the organization's growth strategy in UNY through the use of My Office mailing and filing applications?". In general, organizational changes occur with the use of this application, especially in terms of information flow acceleration, mail flow monitoring, and paper savings. But the changes that are attempted do not necessarily change the organization instantly because there are several factors that hinder the change
\end{abstract}

Keywords: Organizational development, My Office, Universitas Negeri Yogyakarta

\section{Intisari}

Setiap organisasi sangat perlu untuk berkembang seiring dengan perkembangan zaman. Organisasi harus mampu beradaptasi dengan perubahan dalam berbagai aspek kehidupan, seperti perkembangan teknologi, ekonomi, politik, dan perubahan budaya. Dalam mengahadapi perubahan, diperlukan sebuah konsep untuk membantu sebuah organisasi dalam menciptakan respon yang efektif terhadap perubahan ini. Paper ini disusun berdasarkan pengembangan aplikasi persuratan dan kearsipan My Office di Universitas Negeri Yogyakarta (UNY), terutama pada Sub-bagian Tata Usaha dan Kearsipan sebagai pemegang kunci tata persuratan di lingkungan Rektorat UNY, kemudian dianalisis dengan model perkembangan organisasi yang dikembangkan oleh Kurt Lewin. Dengan pendekatan kualitatif-deskriptif, penelitian ini mencoba menjawab pertanyaan: "Bagaimana startegi perkembangan organisasi di UNY melalui penggunaan aplikasi persuratan dan kearsipan My Office?". Secara umum, terjadi perubahan operasional organisasi dengan penggunaan aplikasi ini, terutama dalam hal percepatan arus informasi, monitoring alur surat, dan penghematan kertas. Namun perubahan yang diupayakan tidak serta merta mengubah organisasi secara instan karena ada beberapa faktor yang menghambat perubahan tersebut.

Kata kunci: Perkembangan organisasi, My Office, Universitas Negeri Yogyakarta 


\section{PENDAHULUAN}

Perubahan dibutuhkan setiap organisasi dalam rangka survive and develop (ketahanan dan tumbuh kembang) dalam menghadapi perkembangan zaman. Organisasi dituntut untuk membuat diri mereka lebih efektif, responsif terhadap lingkungan, dan mampu menjalankan bisnisnya secara berkelanjutan. Organisasi juga dituntut untuk mengambil inisiatif dalam berinovasi dan mengelola perubahan, bukan sekedar menanggapi apa yang telah terjadi. Oleh karena itu, pelaku organisasi perlu mempelajari situasi organisaasi saat ini, apakah sudah waktunya untuk melakukan perubahan, dalam bidang apa saja perubahan itu diperlukan, serta bagaimana startegi perubahan yang akan dilakukan. Dengan demikian organisasi menjadi lebih siap dalam menghadapi tantangan zaman.

Organisasi dapat berubah secara terencana maupun tidak terencana. Planned change (perubahan terencana) menurut Smithers (2006, 40-41) adalah perubahan yang dihasilkan dari sebuah keputusan sadar/disengaja untuk mengubah fungsi organisasi, sedangkan unplanned change (perubahan tak terencana) adalah respon terhadap faktor perubahan internal dan eksternal dalam upaya untuk mencegah adanya krisis. Menurut Bennins (1966) dalam Cummings \& Worley $(2005,23)$, konsep perubahan yang direncanakan cenderung berfokus pada bagaimana perubahan dapat dilaksanakan dalam organisasi.

Cummings \& Worley $(2005,4)$ menyatakan bahwa terdapat tiga tren utama adalah membentuk perubahan organisasi, yaitu: (1) globalisasi, yang menuntut organisasi menjalankan fungsinya sebaik mungkin dalam menghadapi perubahan lingkungan; (2) teknologi informasi, yang mendefinisikan bagaimana organisasi mengumpulkan, menyimpan, memanipulasi, menggunakan, dan mentransmisikan informasi agar dapat menurunkan biaya atau meningkatkan nilai dan kualitas produk serta layanan, dan (3) inovasi manajerial, yang menuntut organisasi untuk menyesuaikan diri dalam bentuk baru, seperti jaringan, aliansi strategis, dan perusahaan virtual. Sementara itu, Smithers (2006, 38-43) menyatakan bahwa perubahan organisasi dipengaruhi oleh dua faktor utama, yaitu faktor eksternal dan internal. Faktor eksternal terdiri atas perubahan ekonomi dan perkembangan teknologi informasi. Persaingan ekonomi berpengaruh pada market (konsumen) organisasi, dan perkembangan teknologi informasi berpengaruh kepada kecepatan arus informasi. Sementara itu, faktor internalnya adalah perubahan struktur organisasi dan pengubahan demografi pegawai. Pegawai pada umumnya terlahir dari dan dibesarkan dengan budaya yang berbeda yang berpengaruh pada kebiasaan dan kinerjanya, sehingga perlu perubahan mendasar dari kebiasaan yang kurang baik menjadi kebiasaan yang lebih baik.

Perubahan dan pengembangan organisasi merupakan upaya peralihan untuk memajukan organisasi secara terencana dan mengarah pada suatu tujuan. Menurut Worley dan Feyerherm dalam Cummings dan Worley $(2005,1)$, untuk disebut sebagai proses yang disebut pengembangan organisasi (organizational development), ada 3 hal yang harus diperhatikan, yaitu : (1) harus fokus pada hasil dalam perubahan di berbagai aspek sistem organisasi; (2) harus ada pembelajaran atau pertukaran pengetahuan atau keterampilan; dan (3) harus ada bukti dari peningkatan berdasarkan niat yang dijalankan dalam mengembangkan 
efektifitas dari sistem organisasi.

Porras (1987) dalam Himam (2013, 59) menyatakan bahwa dalam perspektif organizational change and development (OCD), dapat diidentifikasi adanya dua parameter pokok yang yang menjelaskan ke arah mana organisasi seharusnya berubah dan berkembang, yaitu: parameter efectivity (efektifitas) dan parameter quality work life (QWL)/ kualitas hidup anggota organisasi. Kedua parameter ini secara esensi merepresentasikan proses adaptasi yang dilakukan secara terus-menerus oleh organisasi.

Salah satu model awal perubahan yang direncanakan dijelaskan oleh Kurt Lewin, yang dikenal sebagai Lewin's Change Model . Model perubahan Lewin melihat perubahan sebagai modifikasi dari kekuatan yang menjaga perilaku sistem tetap stabil. Dalam Lewin's Change Model dijelaskan bahwa perubahan adalah suatu upaya memodifikasi. Dalam pemahaman ini dijelaskan bahwa setiap kendala yang menghambat pengembangan harus diubah agar dapat membuat sistem lebih stabil. Kendala yang menghambat perubahan biasanya adalah keinginan mempertahankan status quo maupun ketidakmampuan menerima perubahan. Adapun langkahlangkah menurut model ini terdiri dari unfreezing, moving dan refreezing.

Tahap unfreezing meliputi upaya penjelasan mengenai perbedaan antara perilaku yang diinginkan kedepan dengan perilaku yang terjadi sekarang. Pada tahap ini semua bentuk resistensi terhadap perubahan dikurangi dan kebutuhan akan perubahan dikembangkan. Langkah ini biasanya melibatkan pengurangan kekuatan yang mempertahankan perilaku organisasi pada tingkat sekarang. Unfreezing kadang dilakukan melalui proses psychological disconfirmation. Dengan mengenalkan informasi yang menunjukkan perbedaan antara perilaku yang diinginkan oleh anggota organisasi dan perilaku yang saat ini ditunjukkan, anggota diharapkan dapat termotivasi untuk terlibat dalam mengubah aktivitas.

Tahap moving yaitu mengembangkan perilaku yang baru serta melakukan perubahan struktur dan proses dalam organisasi. Pada tahap ini terjadi perubahan dari perilaku lama ke perilaku baru dengan melibatkan intervensi. Sementara itu, tahap refreezing yaitu mengusahakan terjadinya kondisi seimbang dan mengembangkan kebaruan dalam budaya, norma, kebijakan dan struktur. Pada tahap ini, semua perubahan yang telah dibuat dan dikembangkan perlu untuk dipermanenkan, serta diperlukan penggunaan mekanisme pendukung yang menguatkan budaya organisasi baru, seperti budaya organisasi, penghargaan, dan struktur yang baru.

Menurut Tanner (2017), keindahan model Lewin terlihat dari kesederhanaan konsepnya, yaitu hanya terdiri dari tiga langkah. Pertama, meyakinkan para pemangku kepentingan organisasi bahwa perubahan yang diajukan sangat diperlukan (unfreezing). Kedua, lakukan perubahan (moving), dan ketiga, menjadikannya sebagai cara tetap dalam menjalankan organisasi/bisnis (refreezing). Tanner berpendapat bahwa hal tersebut kedengarannya bagus, tetapi jika diterapkan di tempat kerja modern seperti sekarang, model Lewin terlihat terlalu sederhana. Di sinilah model Kotter dapat digunakan dalam kombinasi dengan model Lewin untuk meyakinkan kepemimpinan senior mengenai kebutuhan akan proses yang teratur untuk menerapkan perubahan organisasi. Model Kotter merupakan perpanjangan dari model Lewin. Seperti ditunjukkan pada tabel berikut, delapan langkah Kotter untuk perubahan terdepan sejalan dengan model Lewin sebagai berikut: 
Tabel 1. Perubahan Model Lewin dan Model Kotter

\begin{tabular}{|c|l|}
\hline Kurt Lewin & \multicolumn{1}{c|}{ John Kotter } \\
\hline Unfreeze & $\begin{array}{l}\text { Establish a Sense of Urgency } \\
\text { Create the Guiding Coalition } \\
\text { Develop a Vision and Startegy } \\
\text { Communicate teh Change Vision }\end{array}$ \\
\hline Move & $\begin{array}{l}\text { Empower Broad-Based Action } \\
\text { Generate Short Term Wins } \\
\text { Consolidate Gains \& Make More Change }\end{array}$ \\
\hline Refreeze & Anchor New Approach in the Culture \\
\hline
\end{tabular}

Sumber: Robert Tanner

Sejalan dengan arus globalisasi, organisasi mulai meletakkan pengertian dasar adaptasi dalam kerangka yang terintegrasi dan mengedepankan unsur fluiditas lingkungan yang harus dihadapi organisasi. Konsep tersebut dikenal dengan boudaryless organization dan dikembangkan oleh Ashkenash, dkk pada 1994 (Himam, 2013, 59). Integrasi ini akan berdampak langsung pada efektivitas maupun kualitas hidup anggota organisasi.

Integrasi nilai adaptasi bagi organisasi untuk mencapai efektifitas dan quality work life dapat diperoleh melalui berbagai cara. Salah satu diantaranya adalah penggunaan teknologi informasi dalam persuratan, yaitu penggunaan aplikasi persuratan dan kearsipan elektronik. Powsner, dkk $(1998,1617)$ menyatakan bahwa teknologi informasi menawarkan banyak keuntungan potensial dibandingkan kertas. Kelebihan penggunaan teknologi informasi tersebut adalah kecepatan dan ketepatan dalam membaca dan mengakses data. Bahkan teknologi elektronik dengan media komputer mampu memisahkan data entry dan data recall dalam urutan apapun meskipun tidak dimasukkan atau ditata secara kronologis.

Sellen \& Harper (2001, 25-32) mengungkapkan tiga masalah penggunaan kertas dalam kegiatan administrasi, yaitu: (1) kertas adalah simbol masa lalu/kuno; (2) penggunaan kertas memakan biaya yang besar; dan (3) masalah interaksional yang terbatas pada batas ruang. Keterbatasan penggunaan kertas meliputi: kertas harus digunakan secara lokal, tidak dapat diakses dari jarak jauh, membutuhkan ruang penyimpanan fisik, dan membutuhkan pengiriman fisik. Dokumen berbasis kertas juga sulit direvisi atau diintegrasikan ke dokumen lain, dan statis dalam tampilan visual.

Dalam rangka mencapai tujuan efektifitas, organisasi dituntut untuk membangun sistem yang terkendali dalam kegiatan penyampaian informasi. Universitas Negeri Yogyakarta (UNY), merupakan institusi perguruan tinggi yang mulai menyadari pentingnya perubahan dalam tata persuratan dan kearsipan yang selama ini masih mengandalkan kertas. Sebuah kesenjangan besar terlihat dalam pengolahan surat di UNY. Persuratan dan pengarsipan secara manual membawa dampak buruk bagi organisasi, di antaranya adalah lambatnya arus informasi, keberadaan surat yang sulit ditelusuri, serta penggunaan kertas yang tak terkendali.

Melihat kenyataan tersebut, sebuah external developer menagkap peluang untuk mengembangkan persuratan elektronik dan kemudain ditawarkan ke UNY. Namun karena berbagai pertimbangan, tawaran tersebut kemudian tidak berlanjut menjadi sebuah proyek. Pada awal tahun 2016, UNY 
mengembangkan aplikasi My Office dalam rangka pengurusan surat (mail handling) secara elektronik.

$$
\text { Persuratan (mail handling) }
$$

merupakan bagian dalam

penyelenggaraan kearsipan. Dalam kajian kearsipan, pengurusan surat masuk termasuk dalam bagian penciptaan (creation) arsip. Sementara itu, penciptaan arsip merupakan bagian dari pengelolaan arsip dinamis (records management). Dalam berbagai literatur disebutkan bahwa arsip tercipta melalui pembuatan dan penerimaan. Ricks \& Gow
My Office merupakan sebuah aplikasi yang dikembangkan UNY untuk mengendalikan surat yang berfungsi sebagai arsip dinamis (arsip yang digunakan secara langsung dalam kegiatan administrasi) di lingkungannya. Dengan aplikasi tersebut, terdapat tiga kemungkinan keuntungan yang akan diperoleh oleh UNY dalam menanggapi kesenjangan dalam persuratan, yaitu: (1) percepatan arus informasi, (2) alur surat dapat dipantau secara jelas, dan (3) mengurangi penggunaan kertas (paperless office).

Gambar 1. Alur Penelitian

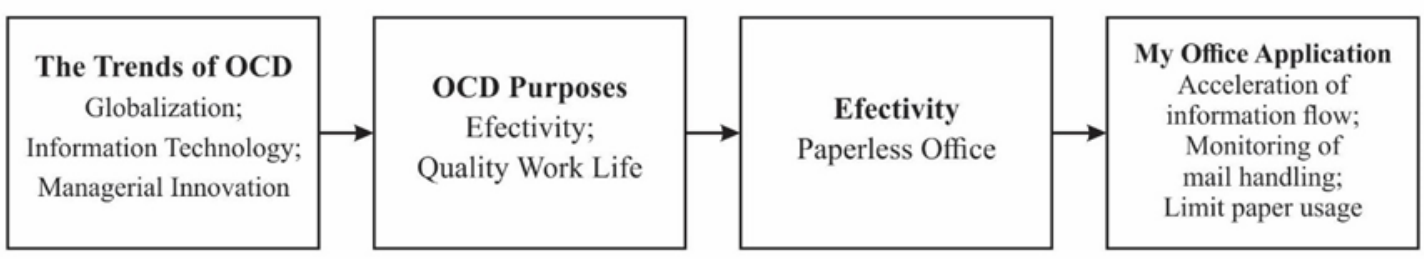

$(1988,4)$ mengatakan bahwa daur hidup arsip menjadi tiga tahap, yaitu: (1) penciptaan atau penerimaan (tahap lahir arsip); (2) penggunaan dan pemeliharaan arsip dinamis (tahap hidup produktif); dan (3) tahap penyusutan arsip dinamis (tahap kematian) atau pemindahan ke tempat arsip statis (reinkarnasi). Sementara itu Atherton (1985:44) menyatakan bahwa pengelolaan arsip dinamis dilaksanakan melalui tahapan: (1) pembuatan atau penerimaan informasi berupa arsip dinamis, (2) klasifikasi arsip dinamis atau informasinya dalam beberapa sistem logis, (3) pemeliharaan dan penggunaan arsip dinamis, dan (4) disposisi arsip diamis melalui penghancuran atau transfer ke lembaga kearsipan. Undangundang nomor 43 tahun 2009 menyatakan bahwa pengelolaan arsip dinamis meliputi penciptaan, penggunaan dan pemeliharaan, dan penyusutan. Dari beberapa literatur tersebut dapat disimpulkan bahwa penerimaan surat termasuk dalam tahap awal pengelolaan arsip dinamis.
Perubahan organisasi dalam rangka memperbaiki dan mengembangkan organisasi bukannya tanpa tantangan. Tantangan tersebut bisa jadi berasal dari internal organisasi, yang diantaranya adalah penolakan terhadap perubahan. Menurut Robbins $(2013,582)$, sumber penolakan terhadap perubahan berasal dari: (1) individu, berupa kebiasaan bekerja dengan gaya lama/kuno, adanya perasaan terancam jika terjadi perubahan, dan anggapan akan berkurangnya penghasilan/faktor ekonomi; dan (2) organisasi, yaitu kelembaman struktural, fokus perubahan yang sangat terbatas, kelembaman kelompok, ancaman terhadap keahlian, ancaman terhadap kekuasaan, dan ancaman terhadap alokasi sumber daya yang mapan.

Penggunaan teknologi informasi di UNY merupakan sebuah tantangan saat ini. Tantangan tersebut dapat dirumuskan dalam pertanyaan berikut: "Bagaimana strategi UNY dalam menggunakan aplikasi My Office untuk 
meraih efektifitas kinerja organisasi?" Berangkat dari pertanyaan umum tersebut, muncul pertanyaan-pertanyaan khusus sebagai berikut:

1. Bagaimana proses inisiasi, adaptasi, dan pemantapan aplikasi My Office dilakukan di UNY?

2. Aspek apa sajakah yang dapat diperoleh kemanfaataanya dalam penggunaan aplikasi My Office di UNY?

\section{METODE PENELITIAN}

Penelitian ini dilakukan dengan pendekatan deskriptif kualitatif. Metode deskriptif menurut Whitney (1960) dalam Nazir (2017) adalah pencarian fakta dengan interpretasi yang tepat. Penelitian kualitatif menurut Pendit (2003, 264) adalah suatu penelitian dengan memberikan perhatian yang seksama dan terinci terhadap hal yang berhubungan dengan suatu fenomena dan memperlakukan fenomena itu secara alamiah sesuai kenyataan yang ada.

\section{HASIL DAN PEMBAHASAN}

\begin{tabular}{llr}
\multicolumn{1}{c}{ Dalam } & rangka & pengembangan \\
organisasi & dalam & mengahadap \\
globalisasi & dan perkembangan teknologi \\
informasi, & UNY mulai & mengembangkan \\
sistem & elektronik dalam tata
\end{tabular} persuratannya. Pada tahun 2012, UNY mendapatkan tawaran dari developer eksternal untuk mengembangkan electronic mailing system. Sistem yang dibangun ini dikenal sebagai e-Office. Setelah diujicobakan hingga tahun 2014, sistem ini dianggap kurang sesuai dengan kebutuhan yang ada di UNY sehingga tawaran sistem ini dihentikan. Oleh karena itu, pimpinan UNY kemudian meminta UPT Pusat Komputer UNY untuk mengembangkan sistem persuratan elektronik yang lebih sesuai dengan kebutuhan. Setelah itu, dibangunlah sistem tata persuratan dan kearsipan elektronik yang kemudian dikenal sebagai aplikasi My Office. Tahap penggunaan aplikasi My Office di UNY meliputi tiga tahapan utama, yaitu: (1) tahap inisiasi, (2) tahap adaptasi, dan (3) tahap penstabilan/pemantapan.

1. Tahap inisiasi penggunaan aplikasi My Office di UNY.

Aplikasi ini mulai dibangun pada 2015. Tahap inisiasi, yang dalam model Lewin dikenal sebagai unfreezing, diperkenalkan aplikasi My Office. Inisiasi dilakukan mulai awal tahun 2016 melalui workshop. Workshop tersebut menghadirkan para pimpinan dan pengelola surat di lingkungan rektorat, fakultas, dan lembaga, dan UPT sebanyak 142 orang. Pada tahap ini diperkenalkan fungsi dan cara penggunaan aplikasi, serta mulai mengupayakan adanya perubahan pandangan mengenai tata persuratan dan kearsipan manual yang perlu dirubah ke dalam sistem elektronik yang lebih efektif.

2. Tahap adaptasi aplikasi My Office di UNY

Sebagai pelaksanaan tahap moving, aplikasi tersebut mulai dipergunakan secara intensif sejak 1 November 2016. Aplikasi tersebut dikelola oleh UPT Pusat Komputer UNY sebagai administrator utama. Hingga saat ini, akses terhadap aplikasi dilingkungan rektorat dibatasi pada level pempinan universitas seperti rektor, wakilwakil rektor, kepala biro, kepala bagian, hingga kepala sub-bagian. Sementara itu, untuk ranah fakultas, akses terhadap aplikasi tersebut dibatasi pada level jabatan struktural fakultas seperti dekan, wakil-wakil dekan, kepala bagian, hingga kepala sub-bagian. Batasan akses pada setiap level adalah membaca, mencetak, dan melakukan disposisi. Aplikasi My Office dikhususkan untuk pengurusan surat masuk dan pengurusan surat keluar internal 
universitas, serta untuk memantau posisi dan lokasi simpan arsip.

3. Tahap stabilisasi aplikasi My Office di UNY

Hingga saat ini tahap refreezing terhadap penggunaan aplikasi My Office di UNY belum dapat terlaksana. Penggunaan My Office di lingkungan UNY belum dipayungi regulasi formal, seperti peraturan rektor atau berupa surat keputusan.

UNY merupakan sebuah universitas dengan struktur organisasi yang kompleks. Kompleksitas struktur organisasi tersebut menyebabkan tingginya kegiatan korespondensi baik internal maupun eksternal. Dalam penelitian ini, aspek-aspek yang diteliti dalam rangka penggunaan aplikasi My Office di UNY adalah: (1) aspek ektifitas arus informasi, (2) aspek monitoring pengolahan surat, dan (3) aspek penghematan penggunaan kertas.

1. Aspek efektifitas arus informasi

Dalam beberapa tahun terakhir, tercatat tidak kurang dari 9000 surat masuk ke Rektorat UNY setiap tahunnya. Pada tahun 2015, tercatat 9985 surat masuk melalui Subbagian TU dan Kearsipan UNY. Sementara itu, pada tahun 2016 tercatat surat masuk sebanyak 9573, dan selama tahun 2017 tercatat 9987 surat masuk.

Dari hasil pengamatan, diketahui adanya kenaikan efektifitas arus informasi di UNY, khususnya di lingkungan rektorat, setelah penggunaan aplikasi My office. Hal ini dapat dilihat dari pengurusan surat di Sub-bagian Tata Usaha dan Kearsipan UNY, yang merupakan pintu masuk bagi setiap surat masuk di lingkungan Rektorat UNY. Sistem tradisional yang digunakan dalam pengurusan surat masuk sebelum dikenalnya aplikasi e-Office dan My Office adalah dengan menggunakan Microsoft Excell. Aplikasi ini memiliki kemampuan data recall yang baik, namun tidak dibekali kemampuan untuk monitoring serta mengirim informasi berbasis internet.

Sebelum menggunakan aplikasi tersebut, surat masuk melalui Subbagian Tata Usaha dan Kearsipan diteruskan kepada Rektor UNY, lalu Rektor memberikan disposisi. Surat tersebut kemudian dikembalikan ke Sub-bagian Tata Usaha dan Kearsipan (Sub-bag TU \& K) untuk dikirimkan kepada tujuan sesuai disposisi. Pengiriman surat tersebut sangat tergantung pada level pengolah surat. Semakin rendah level unit pengolah, semakin panjang jalan yang harus dilalui sehingga arus informasi menjadi semakin lambat. Contoh, apabila pengolah surat adalah level subbagian, maka surat tersebut mengikuti alur seperti berikut:

Surat Masuk $\rightarrow$ Sub-bag TU \& K $\rightarrow$ Rektor $\rightarrow$ Sub-bag TU \& K $\rightarrow$ Wakil Rektor $\rightarrow$ Sub-bag TU \& K $\rightarrow$ Kepala Biro $\rightarrow$ Sub-bag TU \& K $\rightarrow$ Kepala bagian $\rightarrow$ Sub-bag TU \& K $\rightarrow$ Kepala Sub-bagian.

Pada pola tersebut, pengiriman surat antar level tersebut melibatkan surat asli, dan ada kemungkinan beberapa level yang dilalui melakukan duplikasi apabila diperlukan. Sementara itu, setelah penggunaan aplikasi, arus informasi menjadi lebih cepat, seperti pola berikut: 


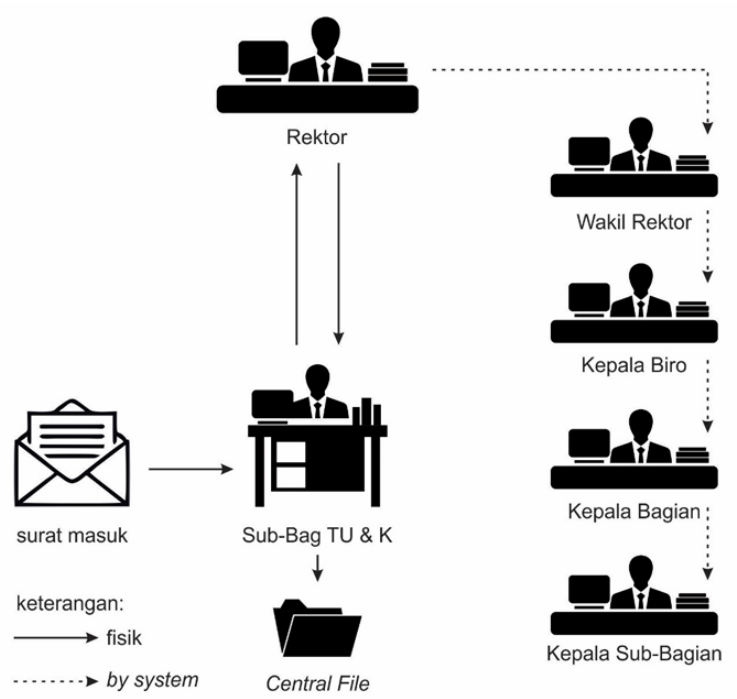

Gambar 2. Arus surat masuk di Rektorat UNY

Penggunaan aplikasi My Office terlihat mampu mengefektifkan arus informasi di lingkungan UNY dalam pengurusan surat masuk. Selain dimensi waktu (kecepatan), pengunaan aplikasi ini juga dapat mengatasi dimensi ruang, karena setiap user level dapat mengakses informasi dari segala tempat dengan jaringan internet.

2. Aspek monitoring pengolahan surat Sub-bagian Tata Usaha dan Kearsipan UNY diberikan wewenang untuk memantau pengolahan surat. Melalui aplikasi My Office, Sub-bagian Tata Usaha dan Kearsipan dapat memantau disposisi terakhir sebagai pengolah surat. Bahkan Sub-bagian Tata Usaha dan Kearsipan dapat melihat level mana sajakah yang telah atau belum membuka aplikasi tersebut sebagai tanda level tersebut telah atau belum membaca surat. Dengan demikian apabila ada pengirim surat menanyakan tindaklanjut dari suratnya, maka Sub-bagian Tata Usaha dan Kearsipan dapat memberikan jawaban secara pasti.

3. Aspek penghematan kertas

Penghematan kertas dapat dilihat dari pengurusan surat keluar, terutama surat keluar internal UNY. Surat keluar yang dibuat oleh UNY tercatat sebanyak 2465 selama tahun 2016, dan meningkat menjadi 4415 surat selama tahun 2017. Jumlah surat keluar tersebut mengindikasikan penggunaan kertas dalam pembuatan surat cukup tinggi. Jumlah tersebut menunjukkan jumlah minimal lembar kertas yang digunakan, karena setiap surat tidak selalu dibuat dalam satu lembar kertas, namun bisa jadi beberapa lembar.

Sebelum menggunakan aplikasi My Office, setiap surat keluar dicetak menggunakan kertas. Namun sejak penggunaan aplikasi, beberapa surat dikirim melalui aplikasi tersebut, terutama untuk surat internal. Beberapa kegiatan yang menggunakan surat internal selama tahun 2017 antara lain undangan mengenai: ground breaking pembangungan gendung IDB 7in1, sosialisasi statuta 2017, upacara hardiknas, upacara harkitnas, upacara harlahpan, upacara hari sumpah pemuda, lokakarya pancasila, peresmian BTN Zone, dan kuliah umum. Selain itu, undangan rutin internal berupa rapat pimpinan dilkasanakan setiap pekan. Pada awalnya, undanganundangan tersebut dicetak pada media kertas. Namun dengan berkembangnya teknologi informasi, pengiriman undangan rapat pimpinan tidak lagi menggunakan kertas tetapi melalui aplikasi My Office. Sementara itu, kegiatan yang melibatkan SDM UNY (dosen dan pegawai) menggunakan pengiriman melalui aplikasi whatsapp dan email. Dengan mengingat jumlah SDM UNY yang cukup besar (tercatat 1270 dosen dan 1074 tenaga kependidikan aktif per 25 Oktober 2017), maka penggunaan teknologi informasi dalam persuratan sangat diperlukan 
untuk penghematan penggunaan kertas.

Hingga akhir tahun 2017, meskipun manfaat penggunaan aplikasi ini mulai dirasakan, pada kenyataannya terdapat berbagai tanggapan terhadap kemunculan aplikasi ini. Beberapa pihak tersebut adalah: (a) pihak yang mempunyai kemampuan menggunakan aplikasi secara intens, menggunakan aplikasi tersebut sambil mengamati kelebihan dan kekurangannya; (b) pihak yang menggunakan aplikasi dan kertas secara bersamaan, yaitu pihak-pihak yang mampu menggunakan aplikasi namun tetap merasa nyaman dengan penggunaan kertas, pada akhirnya tidak mampu mengurangi penggunaan kertas, namun mampu mempercepat arus informasi; dan (c) pihak yang sama sekali belum bersedia menggunakan aplikasi ini, yaitu pihak-pihak yang kesulitan menggunakan aplikasi, masih terjebak pada paradigma obsolete yang boros kertas dan arus informasi menjadi lambat. Melihat kenyataan ini, dapat disimpulkan bahwa perubahan organisasi yang signifikan harus dilakukan secara sederhana dan bertahap mengingat berbagai faktor mempengaruhi penerimaan teknologi baru.

\section{KESIMPULAN DAN SARAN}

Secara umum, dengan pemanfaatan aplikasi ini terjadi perubahan dalam organisasi, yaitu dalam hal percepatan arus informasi, monitoring pengolahan surat, dan penghematan kertas. Namun perubahan sikap dan perilaku belum mencapai ke dalam semua level pengguna informasi. Hal ini disebabkan oleh berbagai faktor, diantaranya adalah: pertama, kebiasaan membaca naskah berbasis kertas masih menjadi pilihan beberapa kalangan di Rektorat UNY.
Untuk merespon hal ini, pimpinan UNY perlu melakukan langkah-langkah strategis guna mengubah kebiasaan tersebut menjadi kebiasaan yang lebih baik. Langkah yang dapat diambil adalah dengan intervensi struktural, karena saat ini aplikasi My Office masih terbatas pada level struktural. Peneliti juga menyarankan agar setiap pegawai dan dosen diberikan hak akses aplikasi ini dengan batasan tertentu, setidaknya sebagai penerima surat, sehingga pengiriman surat dapat dilakukan secara terintegrasi melalui satu sistem yang sama. Kedua, koneksi internet yang tidak stabil menjadi penghambat secara teknis. Rata-rata setiap bulan terjadi empat kali akses jaringan limit/lambat. Hal ini mengakibatkan penggunaan aplikasi My Office menjadi terhambat.

Penggunaan aplikasi My Office terasa dampak positifnya dalam hal persuratan, namun jika dilihat dari tata kearsipan masih memiliki kekurangan. Aplikasi My Office yang belum dapat mengakomodasi pengurusan surat keluar. Dalam ranah ilmu kearsipan, pengurusan surat masuk dan surat keluar terintegrasi ke dalam fase penciptaan dan diolah dengan pemberkasan, yaitu terberkasnya surat masuk dan keluar menjadi satu bagian yang tidak terpisahkan. Saat ini pembuat aplikasi sebaiknya berdiskusi dengan pakar kearsipan guna menghasilkan aplikasi yang dapat mengakomodasi keduanya.

\section{DAFTAR PUSTAKA}

Atherton. Jay. (1985). From Life Cycle to Continuum. Some Thoughts on the Records Management Archives Relationship. Archivaria. 21. 43-51.

Cummings, T.G. \& Worley, C.G. (2005). Organizational Development and Change (8th Edition). Mason, $\mathrm{OH}$ : Thomson South-Western. 
Himam, Fathul. (2013). Talent Management dalam Perspektif Organizational Change and Development. Buletin Psikologi. 21(2). 59-67.

Nazir, Moh. (2017). Metode Penelitian. Bogor: Ghalia Indonesia.

Pendit, P.L., 2003, Penelitian Ilmu Perpustkaan dan Informasi: Suatu Pengantar Diskusi Epistemologi dan Metodologi. Jakarta: JIP-FSUI.

Powsner, S.M, dkk. (1998). Opportunities for and challenges of computerisation. The Lancet. 352.1617-1622.

Ricks, M \& Gow, K. (1988). Information Resources Management. A Records System Approach. 2nd edition. Cincinnati: SouthWestern Publishing.

Robbins, S.P., dan Judge, T.A., (2013). Organizational Behavior. New Jersey: Pearson Education, Inc.

Sellen, A.J. and Harper, R.H.R. (2001). The Myth of the Paperless Office. Bristol, UK: MIT Press.

Smither, R.D. Houston, J.M., \& McIntire, S.A. (2006). Organization Development: Strategies for Changing Environments. New York: Harper Collins College Publishers.

Tanner, Robert.(2017). Unfreeze, Change, Refreeze: Is This a Child's Game? Taken from: https:// managementisajourney.com/ unfreeze-change-refreeze-is-thisa-childs-game/ at October 26, 2017, 09.20 AM.

Undang-undang Nomor 43 tahun 2009 tentang Kearsipan. 